\title{
LEGALITĀTES PIENĀKUMA PĀRKĀPUMS UN KAPITĀLSABIEDRĪBAI NODARĪTO ZAUDĒJUMU NOTEIKŠANAS PROBLEMĀTIKA PRASİBĀ PRET VALDES LOCEKLI
}

\author{
VIOLATION OF DUTY OF LEGALITY AND \\ PROBLEMATICS OF COMPANY'S LOSS \\ DETERMINATION IN CLAIM AGAINST \\ A MANAGEMENT BOARD MEMBER
}

\author{
Evija Novicāne, Dr. iur. cand. \\ Latvijas Universitātes Juridiskās fakultātes doktorante
}

\section{Summary}

In the article, the author analyses the problematic aspects of determination of losses in a situation where a management board member has failed to ensure the lawfulness of company's activities (including a management board member's liability for economically "profitable" violation of the law and liability for sanctions imposed upon the company). The author concludes that in the claim against a management board member, the point of reference for the loss calculation is the reduction of company's property, which is determined using the so-called difference theory. In addition, when calculating the loss, the financial benefit that the company has gained from the violation of the law should be taken into account. The author emphasizes that the liability of a management board member for the sanctions (fines, penalties) imposed to the company must be balanced with general principles of law (in particular - the principle of good faith) and the concept of limited liability.

Atslēgvārdi: valdes locekḷa civiltiesiskā atbildība, legalitātes pienākums, korporatīiā plīvura pacelšana, starpỉbas teorija, zaudējumi

Keywords: civil liability of the management board member, duty to obey the law, piercing the corporate veil, difference theory, losses

\section{Ievads}

Latvijas līdzšinējā tiesu praksē valdes locekḷa pienākums rīkoties kā krietnam un rūpīgam saimniekam lielā mērā ir ticis saistīts ar legalitātes pienākumu. ${ }^{1}$ Tomēr nedz tiesu praksē, nedz arī tiesību literatūrā nav detalizētāk iztirzāts

1 Sk.: Augstākās tiesas Civillietu departamenta 04.07.2018. spriedums lietā Nr. SKC-155/2018 (C30609515), 6.1. punkts; Augstākās tiesas Civillietu departamenta 29.12.2017. spriedums lietā Nr. SKC-351/2017 (C04254513), 7.3. punkts; Augstākās tiesas Civillietu departamenta 27.10.2017. spriedums lietā 
jautājums, kā noteikt atlīizzināmo zaudējumu apmēru situācijā, ja valdes loceklis nav nodrošinājis kapitālsabiedrības (turpmāk - sabiedrība) darbības tiesiskumu. Un šajā ziņā izaicinājumu netrūkst.

Piemēram, komerctiesību doktrīnā tiek diskutēts par to, kā noteikt atlīdzināmo zaudējumu apmēru, ja likuma pārkāpums sabiedrībai ir bijis ekonomiski izdevīgs (tas ir, nav radījis zaudējumus, bet gan gluži pretēji - vairojis pel̦nu²). Diskusijas nerimst arīdzan jautājumā par to, vai valdes loceklim pilnā mērā jāatbild par soda sankcijām, kas sabiedrībai piemērotas par normatīvo aktu pārkāpumiem. Turklāt, ņemot vērā līdzšinējo tiesu praksi, rodas jautājums, kas ir atlīdzināmo zaudējumu noteikšanas atskaites punkts - sabiedrības mantas samazinājums vai kapitāla dalıu vērtības kritums.

Tādējādi ši raksta mērḳis ir iztirzāt zaudējumu noteikšanas problemātiskos aspektus legalitātes pienākuma pārkāpuma gadījumā, tādējādi veicinot tiesiskās domas un tiesu prakses tālākattīstību.

\section{Sabiedrības mantas samazinājums vai kapitāla daḷu vērtības kritums?}

No vienas puses, Komerclikuma 169. panta otrā daļa nepārprotami noteic, ka valdes locekl̦i solidāri atbild par zaudējumiem, ko tie nodarỉjuši sabiedrībai. No otras puses, Latvijas tiesu praksē novērojams konsekvences trūkums jautājumā par to, vai prasībā pret valdes locekli ir vērtējams sabiedrības mantas samazinājums vai kapitāla dalıu vērtības kritums.

Piemēram, Augstākās tiesas Civillietu departamenta 2017. gada 29. decembra spriedumā lietā Nr. SKC-351/2017 (C04254513) norādīts: "Kamēr kapitālsabiedrība ir maksātspējīga, galvenās tās finansiālajā darbībā ieinteresētās personas ir sabiedrības dalībnieki (akcionāri). Šādā situācijā valdes loceklis atbild sabiedrībai par tai nodarìtajiem zaudējumiem. Tà kā komercsabiedrība ir juridiska fikcija un pastāv tikai tās dalībnieku interesēs, faktiski valdes locekḷi atbild par dalībnieku mantas (kapitāla daḷu) vērtības samazināšanos."’ Identiska atziṇa pausta arīdzan Augstākās tiesas Civillietu departamenta 2016. gada 7. jūnija spriedumā lietā Nr. SKC-7/2016 (C39072411). ${ }^{4}$

Minētā atziņa par atlīdzināmo zaudējumu apmēra samērošanu ar kapitāla daļu vērtības samazinājumu ir pretrunā ar mūsdienu komerctiesību doktrīnas izpratni par to, ka valdes loceklim amata pienākumi jāpilda nevis sabiedrības dalībnieku, bet gan sabiedrības interesēs, nodrošinot pēc iespējas efektīvu

Nr. SKC-322/2017 (C28338914), 10. punkts; Augstākās tiesas Civillietu departamenta 29.08.2017. spriedums lietā Nr. SKC-177/2017 (C28466811), 8.1. punkts; Augstākās tiesas Civillietu departamenta 15.06.2017. spriedums lietā Nr. SKC-108/2017 (C02022712), 8.2. punkts; Augstākās tiesas Civillietu departamenta 07.06.2016. spriedums lietā Nr. SKC-7/2016 (C39072411), 7.2. punkts; Augstākās tiesas Civillietu departamenta 12.11.2014. spriedums lietā Nr. SKC-676/2014 (C31405211), 9.2. punkts. Pieejams: https://manas.tiesas.lv/eTiesasMvc/nolemumi [aplūkots 11.02.2020.].

2 Piemēram, ekonomiski izdevīgi parasti ir konkurences noteikumu pārkāpumi.

3 Augstākās tiesas Civillietu departamenta 29.12.2017. spriedums lietā Nr. SKC-351/2017 (C04254513), 7. punkts. Pieejams: https://manas.tiesas.lv/eTiesasMvc/lv/nolemumi [aplūkots 11.02.2020.].

4 Augstākās tiesas Civillietu departamenta 07.06.2016. spriedums lietā Nr. SKC-7/2016 (C39072411), 10. punkts. Pieejams: http://www.at.gov.lv/lv/judikatura/judikaturas-nolemumu-arhivs/civillietudepartaments/klasifikators-pec-lietu-kategorijam/komerctiesibas/valdes-locekla-atbildiba [aplūkots 11.02.2020.]. 
komercdarbību un sekmīgu sabiedrības ilgtermiņa attīstību. ${ }^{5}$ Tas savukārt nozīmē, ka valdes loceklim primāri jārūpējas par sabiedrības kā patstāvìga tiesību subjekta interesēm un attiecīgi - jāsedz zaudējumi, kas ir nodarìti tieši sabiedrībai kā patstāvìgam tiesību subjektam, nevis tās dalībniekiem. Tādējādi jāpiekrìt Latvijas tiesību literatūrā paustajai atziṇai, ka, nosakot zaudējumu apmēru, tiek ñemts vērā tikai pašas sabiedrības mantiskais stāvoklis, kuru neietekmē kapitāla dạı vērtỉbas sarukums valdes locekḷa piel̦autā pārkāpuma dēḷ. ${ }^{6}$ Turklāt minētais princips pilnībā ir attiecināms arīdzan uz viena dalībnieka sabiedrību. ${ }^{7}$

\section{Ekonomiski izdevīgs pārkāpums}

Atbilstoši komerctiesību doktrīnai valdes locekḷa civiltiesiskās atbildības kontekstā zaudējumi ir starpība starp sabiedrības faktisko mantisko stāvokli, kāds radies valdes locekḷa piel̦autā pārkāpuma rezultātā, un paredzamo (hipotētisko) mantas stāvokli, kāds sabiedrībai būtu, ja valdes loceklis būtu rīkojies kā krietns un rūpīgs saimnieks (tā dēvētā starpības teorija). ${ }^{8}$ Taču, pamatojoties uz starpības teoriju, nākas secināt, ka nav pamata Komerclikuma 169. pantā paredzētās atbildības piemērošanai, ja likuma pārkāpums sabiedrībai ir bijis ekonomiski izdevīgs, tas ir, nav radījis zaudējumus, bet gan gluži pretēji - vairojis peḷnu.

Diemžèl šāda nostāja var veicināt to, ka valdes locekḷi, cenšoties gūt pēc iespējas lielāku peḷnu, rīkojas pretēji normatīvo aktu prasībām. Tādējādi komerctiesību doktrīnā tiek diskutēts par to, kā nodrošināt legalitātes pienākuma izpildi ekonomiski izdevīgu likuma pārkāpumu gadỉjumā. Pamatā minētā problemātika rodas tāpēc, ka izdevīgu likuma pārkāpumu gadījumā cietušais ir nevis sabiedrība, bet gan tās personas vai intereses, kuru aizsardzības nolūkā ir pieñemts pārkāptais likums. ${ }^{9}$ Tomēr šìm personām nav prasijuma tiesību pret valdes locekli, pamatojoties uz Komerclikuma 169. pantu, jo tas regulē tikai un vienīgi valdes locekḷa atbildību par sabiedrībai nodarītajiem zaudējumiem.

Nenoliedzami, piel̦autā pārkāpuma ekonomiskais izdevīgums neatbrīvo valdes locekli no kriminālatbildības vai administratīvi tiesiskās atbildības. Ja zaudējumus no likuma pārkāpuma ir cietušas trešās personas, valdes loceklim var tikt piemērota arī delikttiesiskā atbildība, pamatojoties uz vispārējām civiltiesību normām. Tomēr, kā rāda pieredze, šie atbildības veidi nav pietiekami, lai nodrošinātu legalitātes pienākuma izpildi korporatīvajā pārvaldībā. Tādēḷ starptautiskajā praksē arvien vairāk tiek diskutēts arìdzan par korporatīiā plīvura pacelšanu (angḷu val. - piercing the corporate veil) kā instrumentu netaisnprātīgu

5 Sk., piemēram: Keay A. Ascertaining the Corporate Objective: An Entity Maximisation and Sustainability Model. Modern Law Review, September 2008, Vol. 71 (5), pp. 685-688, 691-694.

6 Rudāns S. Valdes locekḷa atbildība par sabiedrībai nodarītajiem zaudējumiem. Grām.: Komerctiesību aktuālie jautājumi Latvijā un Eiropā. Komercdarỉjumi. Atbildība. Komercstrīdi. Rìga: Tiesu namu ağentūra, 2013, 207. lpp.

7 Fleischer H. in: Münchener Kommentar zum Gesetz betreffend die Gesellschaften mit beschränkter Haftung - GmbHG. Band 2: $\$ \$ 35-52$. München: Verlag C. H. Beck, 2016, § 43, Rn. 264.

8 Sk.: Rauter R., Ratka T. in: Ratka/Rauter (Hg). Handbuch Geschäftsführerhaftung mit Vorstandshaftung. 2. Auflage. Wien: Facultas Verlags- und Buchhandels, 2011, Rn. 2/5; arī Kalniņš E. Jēdziena "zaudējumi" izpratnes tālākas attīstǐšanas nepieciešamība. Grām.: Latvijas Republikas Satversmei - 95. Latvijas Universitātes 75. zinātniskās konferences rakstu krājums. Rīga: LU Akadēmiskais apgāds, 2017, 54.-61. lpp.

9 Rosenberg D. Delaware's Expanding Duty of Loyalty and Illegal Conduct: A Step Towards Corporate Social Responsibility. Santa Clara Law Review, 2012, Vol. 52, No. 1, p. 99. 
pārkāpumu apkarošanai gadijjumos, kad valdes loceklis vienlaikus ir arī sabiedrības dalībnieks. N̦emot vērā mūsdienām raksturīgo ekonomiskās aprites globalizāciju un komerctiesību harmonizācijas iniciatīvas, ${ }^{10}$ ārvalstu tiesu prakses un tiesību zinātnes atziṇas par korporatīvā plīvura pacelšanu ir izmantojamas kā iedvesmas avots arī Latvijā. ${ }^{11}$

Korporatīvā plīvura pacelšanas doktrīna pamatā ir vērsta uz kapitālsabiedrības ierobežotās atbildības privilēgijas zaudēšanu, paredzot iespēju panākt kapitālsabiedrības saistību izpildỉjumu no tās dalībniekiem. Tomēr jāatzīst, ka praksē ar šis doktrīnas piemērošanu rodas ievērojamas grūtības, jo trūkst vienotas nostājas jautājumā par to, kad korporatīvā plīvura pacelšana ir tiesiski attaisnojama, kā arī - pastāvot kādiem priekšnoteikumiem un kādā apmērā atbildība par sabiedrības piel̦autajiem pārkāpumiem var tikt prasìta tieši no tās dalībniekiem. ${ }^{12}$

Piemēram, Vācijas tiesību literatūrā ir atzīts, ka korporatīvā plīvura pacelšana kā atkāpe no nošķirtās atbildības principa var apdraudēt tiesisko drošību. ${ }^{13}$ Minētā apsvēruma dẹl Vācijas tiesu praksē priekšroka tiek dota delikttiesiskās atbildības piemērošanai, nevis korporatīvā plīvura pacelšanas doktrīnai. ${ }^{14}$ Savukārt Šveicē ir citāda pieeja - tur tiesu praksē un tiesību zinātnē korporatīvā plīvura pacelšana ir atzīta kā patstāvīgs tiesību institūts, kas kā tiesību normu korigèjošs instruments tiek piemērots acīmredzami netaisnprātīgas rīcības gadījumā, gan norādot, ka tas ir pieḷaujams tikai kā galējais līdzeklis. ${ }^{15}$

Latvijā korporatīvā plīvura pacelšanas doktrīna ir tikai tās attīstības sākumposmā un pagaidām priekšroka tiek dota delikttiesiskās atbildības piemērošanai, nevis pastāvīga tiesību institūta attīstī̌sanai ${ }^{16}$ Šādu pieeju, iespējams, mainīs Latvijas Republikas Augstākās tiesas Senāta Civillietu departamenta 2020. gada 30. janvāra spriedums lietā Nr. SKC-466/2020 (C29250718), kurā, no vienas puses, atzīts, ka "korporatīvais plīvurs ir ar likumu noteiktais kapitālsabiedrības un tās dalībnieka atbildības norobežojums. Tas ir fundamentāls princips, jo mērkis šāda kooperatīvā plīvura radīšanai ir veicināt komerctiesisko darījumu apriti, komercdarbības ātrumu un efektivitāti, lai fiziskām personām nebūtu jābaidās

10 Šajā aspektā ir minami, piemēram, OECD G20/OECD Korporatīvās pārvaldības principi (G20/ OECD Principles of Corporate Governance). Pieejams: http://www.oecd-ilibrary.org/docserver/ download/2615021e.pdf?expires $=1519294226 \& \mathrm{id}=\mathrm{id} \&$ accname $=$ guest $\&$ checksum $=47052318733227 \mathrm{~B}$ BB6FF5C595F88C65C [aplūkots 29.03.2020.], kā arī tiesību zinātnieku izstrādātais Eiropas sabiedrību likuma modelis (European Model Company Act). Pieejams: https://papers.ssrn.com/sol3/papers. cfm?abstract_id=2929348 [aplūkots 29.03.2020.].

${ }^{11}$ Sal.: Levits E. Judikatūra - pamati, problēmas, piemērošana. Latvijas Republikas Augstākās Tiesas Biletens, 2010, Nr. 1/2010, 34. lpp.

${ }^{12}$ Millon D. Piercing the Corporate Veil, Financial Responsibility, and the Limits of Limited Liability. Emory Law Journal, 2007, Vol. 56, No. 5, pp. 1305-1382.

${ }^{13}$ Sk.: Fastrich L. in: Baumbach/Hueck, GmbHG. 20. Auflage. München: Verlag C. H. Beck, 2013, § 13 Rn. 57 f.; Rabensdorf R. Die Durchgriffshaftung im deutschen un rusischen Recht der Kapitalgesellschaften. Frankfurt am Main: Peter Lang GmbH, 2009, S. 89.

${ }^{14}$ Michalski L., Funke I. in: Michalski, GmbHG. 2. Auflage. München: Verlag C. H. Beck, 2010, $\$ 13$ Rn. 400 f.; Rabensdorf R. 2009, S. 80.

${ }^{15}$ Sk.: Kobierski M. Der Durchgriff im Gesellschafts- und Steuerrecht. Schriten zum Steuer- und Wirtschaftsrecht. Band 22. Bern: Stämpfli Verlag, 2012, S. $111 \mathrm{ff}$.

16 Sk., piemēram: Augstākās tiesas Civillietu departamenta 15.06.2017. spriedums lietā Nr. SKC108/2017 (C02022712), 8.1. punkts. Pieejams: https://manas.tiesas.lv/eTiesasMvc/nolemumi [aplūkots 11.02.2020.]. 
no ikkatras komerciālas neveiksmes, kas varētu radīt mantiskas sekas". ${ }^{17}$ No otras puses, spriedumā pamatoti secināts, ka Komerclikuma 137. panta mērḳis nav un nevar būt aizsegs dalībniekiem apzinātu darbību veikšanai, kas rada zaudējumus kreditoriem, iespēju izvairīties no saistībām, apiet likumu. ${ }^{18}$

Jāpiekrìt Latvijas tiesību literatūrā paustajai tēzei, ka dalībnieks nevar atsaukties uz atbildības nošķirtību, ja viņš pats pārkāpj nošķirtās atbildības principu (piemēram, nerespektē sabiedrību kā patstāvīgu tiesību subjektu). Attiecīgi, ja dalībnieks pārkāpj noteikumus, kas nodrošina sabiedrības autonomiju un neatkarību, trešo personu tiesību un likumisko interešu nodrošināšanai korporatīvais plīvurs var tikt pacelts, piemērojot dalïbniekam atbildību par sabiedrības saistībām. ${ }^{19}$ Tomēr būtiski ņemt vērā, ka komerctiesiskā apgrozība tiktu apdraudēta, ja tiktu veiktas nepietiekami izsvērtas atkāpes no nošķirtās atbildības principa. ${ }^{20}$ Tādējādi korporatīvā plīvura pacelšanas institūta piemērošanai jābūt l̦oti pamatotiem apsvērumiem, kas attaisno ierobežotās atbildības privilēgijas zaudēšanu.

\section{Nodarīto zaudējumu izlīdzinājums ar gūtajiem labumiem}

Pat tad, ja sabiedrībai par likuma pārkāpumu ir piemērotas mantiskas sankcijas (naudas sods, soda nauda), tas pats par sevi nesamazina ekonomiskos ieguvumus, kas radušies pārkāpuma (piemēram, aizliegtās vienošanās, karteḷa, negodīgas konkurences, kukul̦ošanas u. c.) rezultātā. Raugoties no tā dēvētās starpības teorijas, atlīdzināmo zaudējumu summa ir nosakāma, ņemot vērā sabiedrības ekonomiskos ieguvumus no pārkāpuma. Tomēr šāda pieeja var veicināt likuma pārkāpumus korporatīvajā pārvaldībā situācijās, kad sagaidāmais labums no likuma pārkāpuma ir lielāks par potenciāli iespējamo sodu (jo īpaši tas attiecināms uz vides aizsardzības aspektiem). Tādējādi, piemēram, vadošie Amerikas Savienoto Valstu korporatīvo tiesību zinātnieki uzskata, ka atlīdzināmo zaudējumu summa nevar tikt samazināta ar sabiedrības ekonomiskajiem ieguvumiem no likuma pārkāpuma. ${ }^{21}$

Jāṇem gan vērā, ka Amerikas Savienotajās Valstīs liela ietekme ir tā dēvētajai dalïbnieku interešu teorijai, kuras pamatdoma ir tāda, ka valdes loceklim amata pienākumi jāpilda tās dalībnieku labā, pamatā ar to domājot pēc iespējas lielāku pel̦nas gūšanu. ${ }^{22}$ Atbilstoši minētajai teorijai korporatīvajā pārvaldībā nav jārēķinās ar citu grupu (piemēram, darbinieku, kreditoru, klientu) interesēm, ja tas nedod labumu sabiedrības dalībniekiem. ${ }^{23}$ Taču, burtiski pieturoties pie šādas

17 Latvijas Republikas Augstākās tiesas Senāta Civillietu departamenta 30.01.2020. spriedums lietā Nr. SKC-466/2020 (C29250718), 10.2. punkts. Pieejams: http://www.at.gov.lv/lv/judikatura/judikaturasnolemumu-arhivs/civillietu-departaments/hronologiska-seciba?year=2020 [aplūkots 04.03.2020.].

18 Ibid.

${ }^{19}$ Lielkalne B. Atkāpe no komerctiesību pamatprincipiem: korporatīvā plīvura jeb ierobežotās atbildības atcelšana. Jurista Vārds, 2020, Nr. 9 (1119), 29. 1pp.

${ }^{20}$ Lìdzīgi: Fastrich L. in: Baumbach/Hueck, GmbHG. 20. Auflage. München: Verlag C. H. Beck, 2013, $\S 13$ Rn. 43 f.; Wagner G. in: Münchener Kommentar zum BGB. Buch 2, 5. Auflage. München: Verlag C. H. Beck, 2009, \$ 826 Rn. 119.

21 Sk., piemēram: Rosenberg D. 2012, p. 103.

${ }^{22}$ Sk. plašāk: Brandt F., Georgiou K. Shareholders vs Stakeholders Capitalism. University of Pennsylvania Law School: Comparative Corporate Governance and Financial Regulation, 2016, pp. 38-43.

23 Sealy L. S. Directors' Wider Responsibilities - Problems Conceptual, Practial and Procedural. Monash University Law Review, 1987, Vol. 13, p. 187. 
pamatnostādnes, pastāv liels risks, ka korporatīvajā pārvaldībā netiek nodrošināta likuma prasību izpilde situācijās, kad likuma neievērošana ir sabiedrībai ekonomiski izdevīga. Tādējādi nostādne, ka likuma pārkāpuma gadījumā valdes loceklim pilnā mērā jāatbild par sabiedrībai piemērotajām sankcijām, nel̦aujot atlīdzināmo zaudējumu summu samazināt ar sabiedrības gūto ekonomisko labumu, zināmā mērā darbojas kā dalībnieku interešu teorijas līdzsvara mehānisms.

Savukārt kontinentālajā Eiropā būtiska ietekme ir tā sauktajai stake-holding (objektīvo interešu) teorijai, kuras pamatideja ir tāda, ka korporatīvā pārvaldība ir nodrošināma, ņemot vērā ne tikai tās dalībnieku intereses, bet arī plašāku interešu loku, tostarp darbinieku, kreditoru, piegādātāju, klientu, vides un vispārējās sabiedrības intereses. ${ }^{24}$ Šāda nostādne principiāli izslēdz iespēju attaisnot likuma pārkāpumu ar peḷnas gūšanas vai ekonomiskā izdevīguma apsvērumiem. Tādējādi kontinentālajā Eiropā ir raksturīga pielaidīgāka nostāja jautājumā par valdes locekḷa tiesībām izvirzìt ierunu par to, ka sabiedrība no likuma pārkāpuma ir ne vien cietusi zaudējumus, bet arī guvusi ekonomiskus labumus.

Piemēram, Vācijas tiesību literatūrā un tiesu praksē ir atzìts, ka, nosakot atlīdzināmo zaudējumu apmēru, jāṇem vērā arī ieguvumi, ko sabiedrība guvusi no likuma pārkāpuma, gan norādot, ka katrs gadījums ir vērtējams individuāli, par mērauklu izmantojot zaudējumu atlīdzināšanas mērkii. ${ }^{25}$ Vienlaikus jāatzīst, ka komerctiesību doktrīnā trūkst vienprātības jautājumā par izlīdzinājuma veikšanu - daži tiesību zinātnieki uzskata, ka šāds "izlīdzinājums" principiāli nav iespējams, citi - ka nav iespējams tikai tad, ja tas ir pretrunā ar pārkāpto priekšrakstu, bet citi - ka gūto labumu vērā neṇemšana būtu pretrunā ar taisnīguma apsvērumiem. ${ }^{26}$

Tomēr, ņemot vērā zaudējumu atlīdzināšanas mērḳi, kā arī saskaṇā ar tā saukto starpības teoriju, ir pamats secināt, ka zaudējumu summa, par kuru valdes loceklim jāatbild legalitātes pienākuma pārkāpuma gadījumā, ir nosakāma, n,emot vērā sabiedrības ekonomiskos ieguvumus. Pretējā gadījumā sabiedrība faktiski iegūtu iespēju iedzīvoties uz normatīvo aktu pārkāpuma rēḳina, ja valdes loceklim būtu pienākums atlīdzināt pilnā mērā sabiedrībai piemērotās sankcijas, neṇemot vērā labumus, ko sabiedrība guvusi no pieḷautā pārkāpuma. ${ }^{27}$ Respektīvi, neveicot "izlīdzinājumu", sabiedrības mantiskais stāvoklis pēc normatīvo aktu pārkāpuma būtu labāks nekā tad, ja likuma prasības tiktu ievērotas. ${ }^{28}$

\section{Grūtības noteikt paredzamo (hipotētisko) mantas stāvokli}

Likuma pārkāpuma gadījumā nereti ir visnotaḷ sarežğīti noteikt to, kāds būtu sabiedrības hipotētiskais mantiskais stāvoklis, ja likuma prasības būtu ievērotas.

\footnotetext{
${ }^{24}$ Marshall Sh., Ramsay I. Stakeholders and Directors' Duties: Law, Theory and Evidence. University of New South Wales Law Journal, 2012, Vol. 35 (1), pp. 292-293.

25 Binder U., Kraayvanger J. Regress der Kapitalgesellschaft bei der Geschäftsleitung für gegen das Unternehmen verhängte Geldbußen. Betriebs-Berater, 2015, Heft 21, S. 1228; Binder S. Grenzen der Vorstandshaftung. Berlin: Duncker \& Humblot, 2016, S. 233.

${ }^{26}$ Haas/Ziemons in: Beck'scher Online-Kommentar GmbHG. 29. Edition, Stand: 01.06.2016, $\$ 43$, Rn. 310.1.

27 Binder U., Kraayvanger J. 2015, S. 1228.

28 Fleischer 2016, $\$ 43$, Rn. 263c.
} 
Piemēram, ja uz sabiedrību ir attiecināms Publisko iepirkumu likums un tā prasỉbas iepirkuma procedūrā nav izpildītas (ietekmēta brīva konkurence, ierobežotas iespējas iepirkuma rezultātā saṇemt un izvēlēties saimnieciski visizdevīgāko piedāvājumu u. tml.), sabiedrības hipotētiskais mantiskais stāvoklis ir atkarīgs no daudziem grūti prognozējamiem apstākḷiem (tostarp pieṇēmuma par iespējamām piedāvājumu alternatīvām), kā rezultātā sabiedrībai nodarīto zaudējumu apmērs var tikt noteikts tikai varbūtības formā.

Varbūtības formā noteikts zaudējumu apmērs savukārt nav pietiekams pamats prasības celšanai pret valdes locekli, jo, cel̦ot prasību pret valdes locekli, prasītājam ir jāpierāda nodarìto zaudējumu apmērs un tiesai, ievērojot Civilprocesa likuma 97. panta trešās daḷas, 183. panta pirmās daḷas un 193. panta piektās dal̦as noteikumus, jāizvērtē prasītāja iesniegtie pierādỉjumi, novērtējot, vai tie apliecina prasības pieteikumā norādītos faktus. ${ }^{29}$

Latvijas tiesu praksē vērojama stingra tiesu nostāja jautājumā par prasītāja pienākumu pierādìt nodarīto zaudējumu apmēru. Piemēram, Augstākās tiesas Civillietu departamenta 2017. gada 30. jūnija spriedumā lietā Nr. SKC-182/2017 (C04332612) uzsvērts: "Vainojamības prezumpcija, pārliekot pierādī̌anas pienākumu no prasītāja uz atbildētāju (valdes locekli), sāk darboties, kad prasītājs atbilstoši sacīkstes principam un Civilprocesa noteikumiem par pierādījumiem un pierādīšanu, ir pierādījis zaudējumu esamību, kas radušies kā amatpersonas rīcības (darbības vai bezdarbības) sekas, kā arī cēlonisko sakaru starp amatpersonas rīcību un zaudējumiem." ${ }^{30}$ Lìdzīga nostāja pausta arī Augstākās tiesas Civillietu departamenta 2015. gada 24. novembra spriedumā lietā Nr. SKC-207/2015 (C28331110): "Prasot atlìdzināt sabiedrības valdes locekḷa rīcības rezultātā radušos zaudējumus, prasītājam jāpierāda ar valdes locekḷa rīcību saistītais sabiedrības mantas samazinājums (pel̦nas atrāvums). Ja nav zaudējumu, tad atbildība neiestājas un atkrīt nepieciešamība vērtēt valdes locekḷa rīcību." 31

Tādējādi jāsecina, ka, stingri pieturoties pie starpības teorijas kā zaudējumu noteikšanas metodikas, likuma pārkāpuma rezultātā sabiedrībai nodarīto zaudējumu apmēra noteikšana un pierādǐšana var izrādīties l̦oti komplicēta vai pat neiespējama. Vācijā šì problemātika tiek risināta ar Vācijas Civilprocesa likuma 287. paragrāfa pirmās daḷas palīdzību, kas paredz tiesai tiesības noteikt atlīdzināmo zaudējumu apmēru pēc sava ieskata, ja jautājums par nodarìto zaudējumu apmēru ir strīdīgs. ${ }^{32}$ Arī Latvijas tiesībās savulaik bija vācu Civilprocesa likuma 287. paragrāfam līdzīga tiesību norma. Proti, Civilprocesa nolikuma ${ }^{33}$ 809. pants paredzēja: "Ja prasībā par naudas prasījumiem tiesa atzīst, ka prasītājam ir tiesības uz atlīdzību, bet ieskata, ka tās lieluma noteikšanā, pēc prasījuma rakstura,

${ }^{29}$ Augstākās tiesas Civillietu departamenta 30.11.2017. spriedums lietā Nr. SKC-343/2017 (C04209810), 9.2.2. punkts. Pieejams: https://manas.tiesas.lv/eTiesasMvc/nolemumi [aplūkots 11.02.2020.].

${ }^{30}$ Augstākās tiesas Civillietu departamenta 30.06.2017. spriedums lietā Nr. SKC-182/2017 (C04332612), 8. punkts. Pieejams: https://manas.tiesas.lv/eTiesasMvc/nolemumi [aplūkots 11.02.2020.].

31 Augstākās tiesas Civillietu departamenta 24.11.2015. spriedums lietā Nr. SKC-207/2015 (C28331110), 6.2. punkts. Pieejams: https://manas.tiesas.lv/eTiesasMvc/nolemumi [aplūkots 11.02.2020.].

$32 \$ 287$ (1) ZPO: "Ist unter den Parteien streitig, ob ein Schaden entstanden sei und wie hoch sich der Schaden oder ein zu ersetzendes Interesse belaufe, so entscheidet hierüber das Gericht unter Würdigung aller Umstände nach freier Überzeugung. Ob und inwieweit eine beantragte Beweisaufnahme oder von Amts wegen die Begutachtung durch Sachverständige anzuordnen sei, bleibt dem Ermessen des Gerichts überlassen.” Pieejams: https://www.gesetze-im-internet.de/zpo/_287.html. [aplūkots 11.02.2020.].

33 Civīlprocesa nolikums. Rīga: Saeimas Kodifikācijas nodaḷa, 1928. 
nav piemērojams vispārējais noteikums par prasības apstiprināšanu ar pierādījumiem, tad viņa var noteikt atlīdzību pēc sava taisnìgā ieskata, kas pamatots uz visu apstākḷu apsvērumu." Analog̣iska norma Civilprocesa likumā nav ietverta, taču tiesības noteikt atlīdzību pēc tiesas ieskata ir noteiktas vairākās materiālo tiesību normās (piemēram, Konkurences likuma 21. pantā).

Lai palielinātu valdes locekḷa atbildības institūta efektivitāti, arī Komerclikuma 169. pantu būtu vēlams papildināt ar tiesību normu, kas paredzētu tiesai tiesības, pamatojoties uz vispusīgu apstākḷu novērtējumu, noteikt atlīdzināmo zaudējumu apmēru pēc sava ieskata, ja valdes loceklis amata pienākumus nav pildījis kā krietns un rūpīgs saimnieks, taču nav iespējams vai ir pārmērīgi grūti precīzi noteikt sabiedrībai nodarīto zaudējumu apmēru.

\section{Valdes locekḷa atbildība par sabiedrībai piemērotajām soda sankcijām}

Pēdējo desmitgažu laikā tiek paredzētas arvien bargākas sankcijas par likuma prasību neizpildi, un tas ir radijis pamatu diskusijām par to, kā atrast saprātīgu lìdzsvaru un taisnīgu rezultātu, kas nodrošinātu atbildīgu korporatìvo pārvaldību, bet neuzliktu nesamērīgu atbildības slogu uz valdes locekḷu pleciem. Jāatzīst, ka jautājums par to, ciktāl valdes loceklim ir jāatbild par zaudējumiem, kas sabiedrībai radušies sakarā ar likuma pārkāpumu, ir viens no korporatīvo tiesību sarežg̀ìtākajiem aspektiem, un starptautiskajā praksē par to nav vienotas nostājas - dažās valstīs tiek atzìta pilnīga valdes locekḷa atbildība, citās novērojama atturīga nostāja. ${ }^{34}$

Piemēram, Lielbritānijas tiesu praksē ir atzìts, ka prasība pret valdes locekli sakarā ar sabiedrībai piemērotajām sankcijām par likuma pārkāpumu ir vērtējama, pamatojoties uz ex turpi causa principu, atbilstoši kuram ir aizliegts gùt tiesisku labumu no paša prettiesiskas rīcības. ${ }^{35}$ Savukārt Vācijas tiesu praksē, no vienas puses, jau izsenis nostiprinājusies atziṇa, ka valdes loceklis atbild par sabiedrības darbības tiesiskuma nodrošināšanu. No otras puses, tiesu prakse jautājumā par valdes locekḷa pienākumu atbildēt par sabiedrībai piemērotajām sankcijām nebūt nav vienota. Piemēram, ThyssenKrupp Group lietā prasība pret valdes locekli, kas tika celta sakarā ar sabiedrībai piemērotajām sankcijām par Konkurences likuma pārkāpumiem, tika noraidīta, norādot, ka šādas atbildības piemērošana valdes loceklim būtu netaisnīga un nesamērīga un faktiski uzliktu uz valdes locekli atbildību risku, kas atbilstoši likumam jāuzņemas pašai sabiedrībai. ${ }^{36}$

Tiesību literatūrā tiek diskutēts arī par citiem apsvērumiem, kuru dēḷ valdes locekḷa atbildība par sabiedrībai piemērotajām likuma pārkāpuma sankcijām nav piel̦aujama vispār vai tikai ierobežotā apmērā. Piemēram, tiek norādīts uz to, ka valdes locekḷa atbildības pienākums ir jāsamēro ar labas ticības principu, ja par likuma pārkāpumu sabiedrībai ir piemērotas sankcijas, kuru apmērs ir noteikts, ņemot vērā sabiedrības mantisko stāvokli (piemēram, par atskaites punktu izmantojot noteiktus procentus no sabiedrības finanšu apgrozijuma). Proti, piemērotās sankcijas neapšaubāmi var radìt būtisku ietekmi uz sabiedrības

\footnotetext{
${ }^{34}$ Nietsch M. Corporate Illegal Conduct and Directors' Liability: an Approach to Personal Accountability for Violations of Corporate Legal Compliance. Journal of Corporate Law Studies, 2018, Vol. 18, No. 1, pp. 151-153.

35 Ibid., pp. 158-159.

36 Ibid., pp. 163-165.
} 
mantisko stāvokli, taču pilnas summas regresa prasība pret valdes locekli visdrīzāk novestu vinuu lìdz pilnīgam finansiālam kraham. ${ }^{37}$

Turklāt starptautiskajā praksē, vērtējot valdes locekḷa atbildību par sabiedrībai piemērotajām sankcijām, būtiska loma tiek piešķirta valdes locekḷa vainojamībai. Piemēram, tiek atzìts, ka valdes loceklis nav vainojams par sabiedrībai piemērotajām soda sankcijām, ja piel̦āvis atvainojumu maldību (pamatā runa ir par gadījumiem, kad ir pārkāpts neskaidrs tiesiskais regulējums) vai pamatoti paḷāvies uz speciālista atzinumu. ${ }^{38}$ Latvijas līdzšinējā tiesu praksē nav atrodams neviens publiski pieejams kasācijas instances tiesas spriedums, kurā būtu konstatēts, ka valdes loceklim par sabiedrībai nodarītajiem zaudējumiem nav jāatbild, jo valdes loceklis nav vainojams zaudējumu nodarīšanā. Tomēr, kā norādījis Egils Levits, Latvijas tiesas kā iedvesmas avotu savai argumentācijai var izmantot ārvalstu judikatūru, jo īpaši to valstu, kuru tiesību sistēma ir tuva Latvijas tiesību sistēmai. ${ }^{39}$ Tādējādi starptautiskā pieredze var noderēt kā izziṇas palīgavots Komerclikuma 169. panta piemērošanā, vērtējot to, vai valdes loceklis ir vainojams par legalitātes pienākuma pārkāpumu.

\section{Kopsavilkums}

1. Nosakot atlīdzināmo zaudējumu apmēru, vērtējams ir tas, ciktāl valdes locekḷa pārkāpuma rezultātā noticis sabiedrības mantas samazinājums, nevis tas, kā valdes locekḷa pārkāpums ietekmējis sabiedrības kapitāla dalı vērtību.

2. Lai aprēķinātu sabiedrībai nodarīto zaudējumu apmēru, jānosaka starpība starp sabiedrības faktisko mantisko stāvokli, kāds radies valdes locekḷa pielautā pārkāpuma rezultātā, un paredzamo (hipotētisko) mantas stāvokli, kāds sabiedrībai bùtu, ja valdes loceklis būtu rīkojies kā krietns un rūpīgs saimnieks.

3. Aprēḳinot zaudējumus, jāṇem vērā sabiedrības ekonomiskie ieguvumi no valdes locekḷa piel̦autā pārkāpuma. Tomēr, ja valdes loceklis negodprātīgi pārkāpis nošķirtās atbildības principu, viņam atbildība var tikt piemērota, pacel ot korporativo plivuru (anglu val. - piercing the corporate veil).

4. Jautājums par valdes locekḷa atbildību par sabiedrībai piemērotajām soda sankcijām ir aplūkojams ārpus Komerclikuma 169. panta rāmjiem, vērtējot katru gadījumu individuāli. Jo īpaši būtiski ir samērot valdes locekḷa atbildības pienākumu ar labas ticības principu un nošķirtās atbildības principu, lai valdes loceklim netaisnīgi vai nesamērīgi netiktu piemērota atbildība, kas atbilstoši komercdarbības būtībai jāuzņemas pašai sabiedrībai.

5. Lai palielinātu valdes locekḷa atbildỉbas institūta efektivitāti, Komerclikuma 169. pantu būtu vēlams papildināt, paredzot tiesai tiesības, pamatojoties uz vispusīgu apstākḷu novērtējumu, noteikt atlīdzināmo zaudējumu apmēru pēc sava ieskata, ja valdes loceklis amata pienākumus nav pildījis kā krietns un rūpīgs saimnieks, taču nav iespējams vai ir pārmērīgi grūti precīzi noteikt sabiedrībai nodarīto zaudējumu apmēru.

\footnotetext{
37 Binder U., Kraayvanger J. 2015, S. 1226 f.

38 Sk.: Fleischer H. 2016, $\$$ 43, Rn. 255; Koch in: Hüffer/Koch, Aktiengesetz. 12. Auflage. München: Verlag C. H. Beck, 2016, \$ 93, Rn. 44; Hölters W. in: Hölters/Bearbeiter, Aktiengesetz: AktG. Kommentar. München: Verlag C. H. Beck/Verlag Franz Vahlen, 2014, §93, Rn. 249.

${ }^{39}$ Levits E. 2010, Nr. 1/2010, 34. lpp.
} 